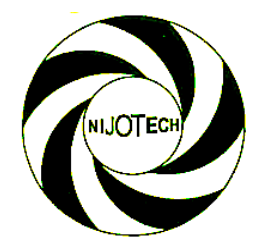

Nigerian Journal of Technology (NIJOTECH)

Vol. 38, No. 2, April 2019, pp. 520 - 525

Copyright(C) Faculty of Engineering, University of Nigeria, Nsukka

Print ISSN: 0331-8443, Electronic ISSN: 2467-8821

www.nijotech.com

http://dx.doi.org/10.4314/njt.v38i2.31

\title{
EVALUATION OF THE ENGINEERING PROPERTIES OF CASHEW KERNEL OBTAINED FROM DIFFERENT PLANTATIONS IN NSUKKA
}

\author{
N. N. Aneke ${ }^{1}$, O. Ojike ${ }^{2,}{ }^{*}$, and K. Ozor ${ }^{3}$ \\ 1, 2, 3, Agricultural \& Bioresources Engineering, Univ. OF Nigeria, NSUKKA, ENUGu StATE, NIGERIA \\ E-mail addresses: ${ }^{1}$ nneoma.aneke@unn.edu.ng, ${ }^{2}$ onyekwere.ojike@unn.edu.ng, \\ 3 kenechukwu.ozor@unn.edu.ng
}

\begin{abstract}
In this study, the engineering properties of cashew kernels grown in Nsukka were evaluated. The experiments were carried out in replicates from different plantations in order to achieve near accurate average values. The results showed no significant difference in the physical and thermal properties while terminal velocity, coefficient of friction, compressive force and stress were significantly different. Thus, since the physical properties were significantly the same then a processing system developed using the property values of a particular batch of kernel can be conveniently used with any other batch of the kernel. However varying force applications are to be used depending on the batch due to significant differences in the values of the mechanical properties and end-product of operation the same due to the fact that deformation was significantly the same. The thermal response of any batch will be the same since the thermal properties were significantly the same.
\end{abstract}

Keywords. thermal, mechanical, physical, cashew, kernel, processing.

\section{INTRODUCTION}

Cashew kernel is part of the nut of the fruit of the tree (AnarcardiumOccidentale L.) (Figure 1). Cashew tree, a long-lived perennial plant is native to northeast region of Brazil but has expanded to become global tropical evergreen tree [1]. Some varieties of cashew tree can reach up to $14 \mathrm{~m}$ in height [2].The cashew nuts are thermally processed to get kernels. The kernels may be further processed into value-added products such as fried, roasted, or chocolate-coated and flour kernels, and various confectioneries [3, 4].

In 2015, global production of cashew kernel was 738,861 tonnes, led by India and Côte d'Ivoire each with $23 \%$ of the world total [5]. The health benefits associated with the kernels are: reduction in mortality rate and cardiovascular disease, especially in case of stroke, a decreased risk of metabolic syndrome and diabetes, Prevents cancers, good for bone health, skin health, healthy brain function and nerve health, help weight loss [6-11]. The overall composition of the kernel is protein $21 \%$, fat $46 \%$ and carbohydrates $25 \%$ [12].

\footnotetext{
* Corresponding author, tel: +234 - 803 - $629-5738$
}

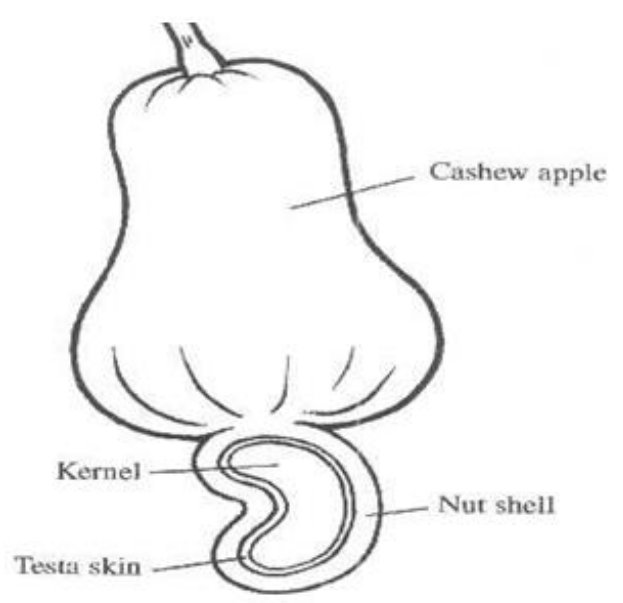

Figure 1: A cashew fruit

In processing and handling of food and agricultural materials, their' properties need to be determined in order to maintain or increase its quality. These properties which include physical and thermal properties among others are not constant but fluctuate depending on the variety of the product (see for example Figure 2). 


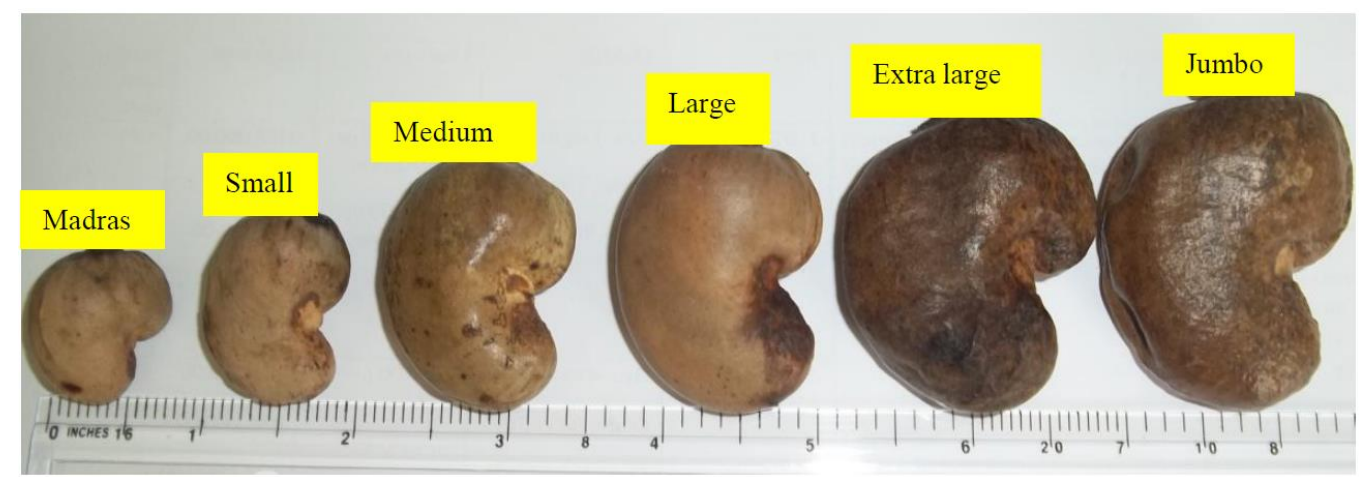

Figure 2: Different sizes of Cashew nuts [15].

Knowing and understanding the physical properties of a food product is very important in designing of systems/machines, general processing and developing structures for storage [13]. How food materials and products react under heat applications is influenced by the thermal properties of the material, while mechanical properties determine how the materials react to the application of force to them [14].

In other to develop machines and equipment for processing and handling of the kernels, there is then the need to study the properties of cashew kernels especially the physical, mechanical and thermal properties. Several studies have been done on the evaluation of properties of cashew kernel $[14,16]$. However, the values of these properties differ from study to study due to location and variety. Hence, there is the need to study the properties of cashew kernels grown in Nsukka in order to generate data that could be used for machine/system designs for Nsukka cashew kernel processing.

The engineering properties considered were limited to only the physical, mechanical and thermal properties. Data on engineering properties of a biomaterial are dependent on a number of factors such as variety and the climatic environment where it is cultivated [17]. Thus, making it desirable that the engineering properties of cashew kernels grown in Nsukka cashew plantations be determined.

\section{MATERIALS AND METHODS}

\subsection{Sample Preparation}

Five kilograms of cashew nuts were collected from Nsukka cashew plantations in Enugu State, Nigeria. The plantations were Obimo, Ogbede and Orba cashew plantations identified as samples $A, B$ and $C$ respectively. The nuts were sorted according to their plantation locations. The sample nuts were cleaned thereafter soaked in water which reduced scorching when roasted in a drum. Then the sample was roasted and cracked manually to get the kernels [18]. The kernels were conditioned to $5 \%(\mathrm{wb})$ moisture content using a standard oven method at $103 \pm 2^{\circ} \mathrm{C}$ [19]. To this, the kernels were sprayed with water, then put inside a polythene bag and tied. This was then kept for five days in a refrigerator set at five degree Celsius to allow the moisture content to be uniform. Then it was brought out and dried in oven until the moisture content dropped to $5 \%$. For proper storage of cashew kernel, the recommended moisture content is $5 \%$ (wet basis) [20].All tests were in triplicates.

\subsection{Determination of physical properties}

For the physical properties, 100 samples of kernels randomly selected were evaluated by the method of Mohsenin [21] using equations (1) - (3) to determine the size and the sphericity index of the kernels where $g_{m d}, a_{m d}, s_{i}, l, b$ and $t$ represent the geometric mean diameter, arithmetic mean diameter, sphericity, length, width and thickness respectively.

$$
\begin{aligned}
& g_{m d}=(l b t)^{\frac{1}{3}} \\
& a_{m d}=\frac{(l b t)}{3} \\
& s_{i}=\frac{g_{m d}}{l}
\end{aligned}
$$

Equation 4 was used to determine the bulk density $\left(b_{d}\right)$ using the method of Mohsenin [23] where $m_{k}$ and $c_{v}$ are the mass of the kernels and volume of the cylinder respectively. The Specific Gravity was determined by the method of Ogungbenle [24].

$$
b_{d}=\frac{m_{k}}{c_{v}}
$$

The kernels' true density $\left(t_{d}\right)$ was evaluated using equation 5 as discussed in [24] where $m$ and $v$ are the mass and volume of each kernel.

$$
t_{d}=\frac{m}{v}
$$




\subsection{Determination of mechanical Properties}

The method of [22] was used to evaluate the coefficient of friction $(\mu)$ while the angle of repose was determined by the 'emptying method' $(\theta)$ [25]. In this method, kernels were poured in to a cylinder kept on top of a plain area surface as described by Obi and Offorha [25]. To form natural slope, the cylinder was gradually and carefully raised to allow the samples flow gradually down. Considering the height and diameter of the pile formed, the dynamic angle of repose was then given as,

$$
\theta=\tan ^{-1} \frac{2 l}{d}
$$

Where, $l(m)$ is the pile height and $d(m)$ is the pile diameter.

The Compressive force, Stress and Deformation were analysed using a Hounsfield Monsanto Tensometer [14]. During the tests, the kernels were loaded with the position of the intermediate (width) diameter as the load bearing axis. Each kernel was compressed with a motion probe at a constant speed until the specimen fractured. The compressive force and deformation values were recorded from the data chart of the Tensometer (Figure 3).

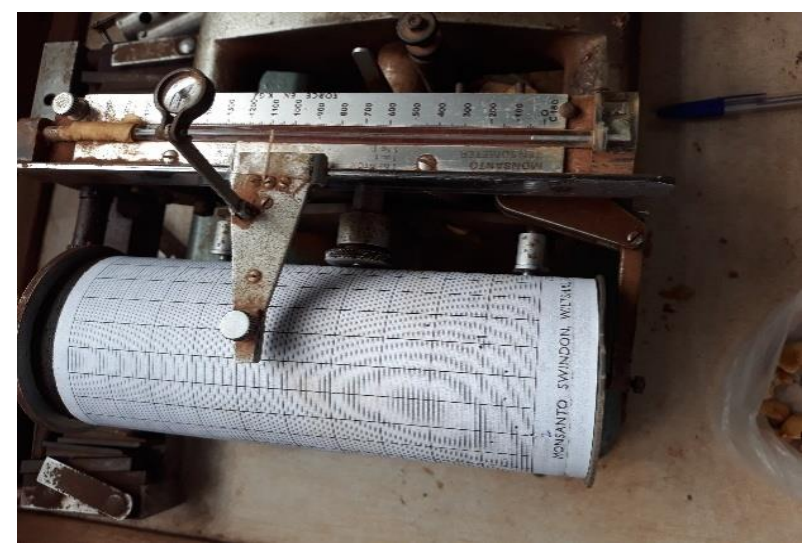

Figure 3: Tensometer chart

The terminal velocity was determined by measuring the fluid velocity required to suspend the sample in a vertical fluid stream in a calibrated cylinder. The samples were dropped into a cylinder filled with glycerine. As the sample moved down, the resistance force is said to be zero and the initial acceleration as $g$. As its speed increased, the resisting force increased until it was equal in magnitude to the sample's weight. Using Newton's second law:

$$
\Sigma F_{y}=m g-k v=m a=0
$$

The acceleration became zero and there was no further increase in speed. The terminal velocity $V_{t}$, was then calculated as:

$$
V_{t}=\frac{m g}{k}=\frac{\sqrt{2 m g}}{A_{p} \rho C_{D}}
$$

Where, $\mathrm{m}=$ mass of sample, $\mathrm{kg}, \mathrm{g}=$ acceleration due to gravity, $\mathrm{m} / \mathrm{s}^{2}, \mathrm{k}=$ proportionality constant, N.s/m, $A_{p}=$ projected area of sample, $\mathrm{m}^{2}, C_{D}=$ drag coefficient, $\rho=$ density of liquid, $\mathrm{kg} / \mathrm{m}^{3}$

\subsection{Determination of thermal properties}

The method outlined in [26] was used to evaluate the

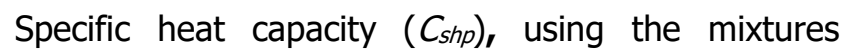
method where samples of given mass and temperature were en massed in water contained in a calorimeter made of copper material and stirred continuously until an equilibrium temperature was reached. The calorimeter was properly insulated to avoid heat loss. $C_{s h p}$ was then calculated as:

$$
C_{s h p}=\frac{\left(M_{o c} C_{o c}+M_{w a} C_{w a}\right)\left(\mathrm{T}_{\mathrm{f} l}-\mathrm{T}_{w a}\right)}{M_{k s}\left(\mathrm{~T}_{k s}-\mathrm{T}_{e}\right)}
$$

Where,

$\mathrm{C}_{\text {shp }}=$ specific heat of sample, $\mathrm{J} / \mathrm{kg}{ }^{\circ} \mathrm{C}$

$\mathrm{C}_{\underline{\mathrm{oc}}}=$ specific heat of calorimeter, $\mathrm{J} / \mathrm{kg}{ }^{\circ} \mathrm{C}$

$\mathrm{C}_{\text {wa }}=$ specific heat of water, $\mathrm{J} / \mathrm{k} \mathrm{g}{ }^{\circ} \mathrm{C}$

$M_{\text {wa }}=$ mass of water, $\mathrm{kg}$

$M_{\mathrm{oc}}=$ mass of calorimeter, $\mathrm{kg}$

$M_{\mathrm{ks}}=$ mass of sample, $\mathrm{kg}$

$\mathrm{T}_{\mathrm{ks}}=$ initial temperature of sample, $\mathrm{K}$

$\mathrm{T}_{\mathrm{fl}}=$ equilibrium (final) temperature, $\mathrm{K}$

$\mathrm{T}_{\text {wa }}=$ initial temperature of water, $\mathrm{K}$

$\mathrm{T}_{\mathrm{e}}=$ equilibrium temperature, $\mathrm{K}$

The principle outlined in [27] was used to evaluate the thermal conductivity $(K \mathrm{CO})$ of the cashew kernels. A cylinder made of plastic and fixed with two thermocouples at the central point was filled with the kernel samples. The thermocouples were for temperature measurement. Other details of the set up are as discussed in [27]. Then $K c O$ is given as:

$$
k c o=\frac{Q \ln \mathrm{t} 2 / \mathrm{t} 1}{4 \pi\left(\mathrm{T}_{\mathrm{t} 2}-\mathrm{T}_{\mathrm{t} 1}\right)}
$$

Where, $\mathrm{Q}=$ heat input, $\mathrm{W} / \mathrm{m} ; \mathrm{t}_{1}=$ initial time, $\mathrm{s}$ $\mathrm{t}_{2}=$ final time, $\mathrm{s} ; \mathrm{T}_{\mathrm{t} 1}=$ initial temperature, ${ }^{\circ} \mathrm{C}$ $\mathrm{T}_{\mathrm{t} 2}=$ final temperature, ${ }^{\circ} \mathrm{C}$

\subsection{Statistical analysis}

The different results were analyzed statistically using GenStat Discovery Edition software. The cashew plantations identified as samples $A, B$ and $C$ respectively served as the treatment. This test was done for the observed data. This test was used to determine if there is any significant difference 
between the location as regard their different properties. If there was a significant difference, Least Significant Difference (LSD) was conducted to detect the difference between the means.

\section{RESULTS AND DISCUSSIONS}

\subsection{Physical properties}

The values of the physical properties of the samples considered were as shown in Table 2 where the superscripts represent the level of significance at $5 \%$ levels of probability level. The same letter means the difference in means are not significant. As expected all the properties considered had varying values for different replications of cashew kernels samples.

This is in agreement with literature which recorded varying values for a particular physical property $[3$, 16]. However, when subjected to statistical analysis, it was found that the physical properties were all significantly the same at $5 \%$ probability level. This then implies that the cashew kernels can be handled and processed using the same machine/mill.

\subsection{Mechanical properties}

Table 3 showed the mechanical properties of the cashew kernels where the superscripts represent the level of significance at $5 \%$ levels of probability level in means of the properties in descending order ' $a$ ' representing the highest in value. The same superscript letter signifies that there is no significant difference among the value means. It can be observed that porosity, angle of repose and deformation were significantly the same while terminal velocity, coefficient of friction, compressive force and stress were significantly different. This shows that with the application of different and appropriate amounts of force to the kernels during processing and handling operations the same level of result, that is, deformation and porosity will be actualised.

\subsection{Thermal Properties}

The differences between mean values of the thermal properties of the kernels are equally shown in Table 3 where the superscripts represent the level of significance at $5 \%$ levels of probability level. The same letter indicates that the difference in means is not significant. As can be observed, there were variations in the values of any given property. This is in agreement with literature which recorded varying values for a particular property $[3,16]$. However, when the values were statistically evaluated, it was observed that of the two thermal properties there was no significant difference among them. From this result, it can be said that the effect of heat on kernels are the same.

Table 2: Mean values of the physical properties of Cashew kernels

\begin{tabular}{lccc}
\hline Properties & A & B & $C$ \\
\hline Length $(\mathrm{mm})$ & $26.7 \pm 0.31^{\mathrm{a}}$ & $24.5 \pm 0.30^{\mathrm{a}}$ & $25.6 \pm 0.54^{\mathrm{a}}$ \\
Width $(\mathrm{mm})$ & $11.6 \pm 0.17^{\mathrm{a}}$ & $10.71 \pm 0.11^{\mathrm{a}}$ & $9.8 \pm 0.06^{\mathrm{a}}$ \\
Sphericity $(\%)$ & $53.66 \pm 0.16^{\mathrm{a}}$ & $52.47 \pm 0.28^{\mathrm{a}}$ & $53.21 \pm 0.73^{\mathrm{a}}$ \\
Bulk density $\left(\mathrm{kg} / \mathrm{m}^{3}\right)$ & $559.3 \pm 11.34^{\mathrm{a}}$ & $640.6 \pm 3.37^{\mathrm{a}}$ & $719.6 \pm 18.18^{\mathrm{a}}$ \\
True density $\left(\mathrm{kg} / \mathrm{m}^{3}\right)$ & $1176.5 \pm 9.38^{\mathrm{a}}$ & $1250 \pm 1.56^{\mathrm{a}}$ & $1117.6 \pm 3.89^{\mathrm{a}}$ \\
Specific gravity & $0.893 \pm 0.01^{\mathrm{a}}$ & $0.893 \pm 0.05^{\mathrm{a}}$ & $0.893 \pm 0.08^{\mathrm{a}}$ \\
\hline
\end{tabular}

Table 3: Mean values of the mechanical and thermal properties of cashew kernels

\begin{tabular}{|c|c|c|c|}
\hline & $\mathbf{A}$ & B & $\mathbf{C}$ \\
\hline \multicolumn{4}{|l|}{ Mechanical properties } \\
\hline Porosity (\%) & $52.1 \pm 1.26^{a}$ & $48.8 \pm 0.3^{a}$ & $39.6 \pm 1.82^{a}$ \\
\hline Angle of repose $\left(^{0}\right)$ & $35.30 \pm 0.06^{a}$ & $35.30 \pm 1.01^{\mathrm{a}}$ & $35.30 \pm 0.54$ a \\
\hline Terminal velocity $(\mathrm{m} / \mathrm{s})$ & $2.180 \pm 0.07^{b}$ & $3.839 \pm 0.10^{\mathrm{a}}$ & $3.224 \pm 0.01$ \\
\hline Coefficient of friction & $0.5286 \pm 0.01^{b}$ & $0.6316 \pm 0.01^{a}$ & $0.5441 \pm 0.01^{b}$ \\
\hline Compression force $(\mathrm{N})$ & $675 \pm 21.6^{b}$ & $875 \pm 11.21^{a}$ & $975 \pm 6.12^{\mathrm{a}}$ \\
\hline Stress $\left(\mathrm{N} / \mathrm{mm}^{2}\right)$ & $0.91 \pm 0.07^{b}$ & $1.75 \pm 0.05^{b}$ & $1.66 \pm 0.04$ a \\
\hline Deformation $(\mathrm{mm})$ & $5.50 \pm 0.04{ }^{a}$ & $5.75 \pm 0.05^{\mathrm{a}}$ & $6.00 \pm 0.18^{a}$ \\
\hline \multicolumn{4}{|l|}{ Thermal properties } \\
\hline Specific heat capacity $(\mathrm{J} / \mathrm{Kg} / \mathrm{K})$ & $1688.9 \pm 27.89^{a}$ & $1644.5 \pm 50.13^{\mathrm{a}}$ & $1627.3 \pm 37.05^{\mathrm{a}}$ \\
\hline Thermal conductivity (W/mK) & $0.2423 \pm 0.01^{\mathrm{a}}$ & $0.2019 \pm 0.02^{a}$ & $0.2173 \pm 0.01^{a}$ \\
\hline
\end{tabular}




\section{CONCLUSION}

From the analysis of properties of cashew kernels obtain from different plantations within Nsukka area it can be concluded that since there was no significant different among the physical properties then a processing system developed using the property values of kernels processed from a particular plantation can conveniently be used with any other kernel from other plantations. However varying force applications are to be used depending on the characteristics of the kernel of a given plantation. This is because there were significant differences in the values of the mechanical properties examined and the end-product of the processing operation will be the same due to the fact that deformation in all cases was significantly the same. Equally the thermal response of different samples of kernel will be the same since no significant difference was observed in the cashew kernels' thermal properties.

Hence, a cashew kernel processing system/machine designed using the properties of a given cashew kernel as design parameters can conveniently be used for processing of any other sample of cashew kernel grown in Nsukka.

\section{REFERENCES}

[1] Asogwa, E. U., Hammed, L. A. and Ndubuaku, T. C. N. "Integrated production and protection practices of cashew Anarcardiumoccidentale, in Nigeria", African Journal of Biotechnology 7(25), pp.4868-4873, 2008.

[2] Morton, J. F. (1987). "Cashew apple, Anacardiumoccidentale L".Fruits of warm climates, Julia F. Morton.Center for New Crops and Plant Products, Department of Horticulture and Landscape Architecture, Purdue University, W. Lafayette, IN. pp. 239-240. ISBN 978-09610184-1-2.

[3] Bart-Plange, A., Mohammed-Kamil, A. P., Addo, A. and Teye, E. "Some physical and mechanical properties of cashew nuts and kernel grown in Ghana", International Journal of Science and Nature 3(2), pp.406-415, 2012a.

[4] Phillippa C. South Africa Eats, Cape Town: Quivertree, 2009.

[5] Elakkiya, E., Sivaraj, P. and Vijayaprabhatar, A. "Growth and performance of cashew nut products in India-an analysis", International Journal of Current Microbiology and Applied Sciences 6(6), pp.1817-1823, 2017.
[6] Kris-Etherton, P. M., Hu, F. B., Ros, E. and Sabate, J. "The role of tree nuts and peanuts in the prevention of coronary heart disease: multiple potential mechanisms", Journal of Nutrition 138, pp.1746-1751, 2008.

[7] Kendall, C. W., Esfahani, A., Josse, A. R., Augustin, L. S., Vidgen, E. and Jenkins, D. J. "The glycemic effect of nut-enriched meals in healthy and diabetic subjects", Nutrition, Metabolism and Cardiovascular Diseases 21(1), pp.34-39, 2011.

[8] Ros, E., Tapsell, L. C. and Sabate, J. "Nuts and berries for heart health", Current Atherosclerosis Report 12, pp.397-406, 2010.

[9] Estruch, R., Ros, E., Covas, M. I., Corella, D., Arós, E. \& Gómez-Gracia, E. "Primary prevention of cardiovascular disease with a Mediterranean diet", The New England Journal of Medicine 368, pp.1279-1290, 2013.

[10] Fernández-Montero, A., Bes-Rastrollo, M., Beunza, J. J., Barrio Lopez, M.T., FuenteArrillaga, C. and Moreno-Galarraga, L. "Nut consumption and incidence of metabolic syndrome after 6-year follow-up", Public Health Nutrition 16, pp.2064-2072, 2013.

[11] Mitjavila, M. T., Fandos, M., Salas-Salvadó, J., Covas, M. I., Borrego, S. and Estruch, R. "The Mediterranean diet improves the systemic lipid and DNA oxidative damage in metabolic syndrome individuals. A randomized, controlled, trial", Clinical Nutrition 32, pp.172-178, 2013.

[12] Ohler, J. G. Cashew, Amsterdam: Department of Agricultural Research, Royal Tropical Institute, 1979.

[13] Esref, I. and Halil, Ü. "Moisture-dependent physical properties of white speckled red kidney bean grains", Journal of Food Engineering 82, pp.209-216, 2007.

[14] Bart-Plange, A., Ado. A., Kumi, F. and Piegu, A. $\mathrm{K}$. "Some moisture dependent thermal properties of cashew kernel", Australian Journal of Agricultural Engineering 3(2), pp.65-69, 2012

[15] Adeigbe, O. O., Olasupo, F. O.,Adewale, B. D andMuyiwa, A. A."A review of cashew research and production in Nigeria in the last four decades",Scientific Research and Essays 10(5),pp.196-209, 2015.

[16] Isa, J. and Oguntuase, I. J. "Determination of Some Physical and mechanical properties of cashew Kernel (Anarcardiumoccidentale L)", Journal of Sustainable Technology 6(2), pp.104$112,2013$. 
[17] Nejo, R. and Oloko, S. A. "Determination of some physical properties of cashew nut", International Journal of Innovative Science, Engineering and Technology 3(10), pp.167-173, 2016.

[18] Azam-Ali, S. H and Judge, E. C. Small-scale cashew nut processing, Warwickshire: FAO Publication, 2004.

[19] Dursun I., Dursun E. and Tugrul, K. M. "Some physical properties of sugar beet seed", Journal of Stored Products Research 43, pp.149-155, 2006.

[20] Azam-Ali, S. H and Judge, E.C. Small scale cashew processing,Wickshire: Schumacher Center for Technology and Development, 2001.

[21] Mohsenin, N. N. Physical properties of plant and animal materials: Structure, physical characteristics and mechanical properties. $2^{\text {nd }} e d$, New York: Gordon and Breach Science Publishers, 1986.

[22] Kachru, R. P., Gupta, R. K. and Alam, A. Physicochemical constituents and engineering properties of food crops, Jodhpur: Scientific Publishers, 1994.

[23] Mohsenin, N. N. Thermal properties of foods and agricultural materials, New York: Gordon and Breach Science Publishers, 1980.

[24] Ogungbenle, H. N. "Chemical, functional properties and amino acid composition of raw and defatted cashew kernel", American Chemical Science Journal 4(3), pp.348-356, 2013.

[25] Obi, F. and Offorha, L. C. "Moisture-dependent physical properties of melon (Citrulluscolocynthis L.) seed and kernel relevant inbulk handling", Cogent Food and Agriculture 1, pp. 1-14, 2015.

[26]Aviara, N. A. andHaque, M. A. "Moisture dependence of thermal properties of sheanut kernel", Journal of Food Engineering 47,pp.109113, 2001.

[27] Sweat V. E. and Haugh C. G. "Thermal conductivity probe for small food samples", Transactions of the American Society of Agricultural Engineers 17(1), pp.56-58, 1974. 